\title{
The Land of Mourning: A Conversation with Adeela Suleman
}

\author{
Palvasha Shahab
}

\begin{abstract}
Adeela Suleman is a globally celebrated artist and sculptor. She was front and centre of the artists' response to the Ali Enterprises Factory Fire of 2012. Under her leadership, the Vasl Artists' Association sent out a call for submissions to artists across Pakistan and the overwhelming response was curated in the form of the exhibition titled: 'Awaaz Baldia Factory Inferno: Artists Respond' which was hosted by the Arts Council of Pakistan in February 2013. Her monument dedicated to those who lost their lives in the fire was also part of the one year anniversary of the fire has been placed at the Pakistan Institute of Labour Education and Research (PILER). She also facilitated several international collaborations and artists intending to engage with the fire. Palvasha Shahab sat down with her to explore her thoughts about the role that art and artists play in the face of calamities and social injustices, her relationship to Karachi and her own response to the fire.
\end{abstract}

Keywords Labour rights · Factory fire $\cdot$ Social justice $\cdot$ Political art · Interdisciplinary perspectives $\cdot$ Karachi $\cdot$ Global south

Adeela Suleman is a globally celebrated artist and sculptor. She is an Associate Professor, and was the Head of Department for Fine Arts, at the Indus Valley School of Art and Architecture in Karachi from 2008 till 2019. She is also the founding member and director of the Vasl Artists' Association, an artist led residency program part of Triangle network, UK, that regularly hosts artists from around the world. She was a key voice in the artists' response to the Ali Enterprises Factory Fire of 2012 and her work features prominently amongst responses to the Fire. Along other artists, her work was very important in drawing global attention to the human societal loss caused by the fire.

\footnotetext{
P. Shahab (ه)

Rasheed Razvi Centre for Constitutional and Human Rights (RCCHR), Karachi, Pakistan

Legal Aid Foundation for Victims of Rape and Sexual Assault (LAFRSA), Karachi, Pakistan e-mail: palvasha.shahab@columbia.edu
} 
Historically, artists have played an important role in labor movements highlighting the plight of workers and bringing it to public attention. American photographer Lewis Hine jarred public and policy makers with his work on the realities of child labour and lack of worker safety in the steel and construction industries. Famous novelist Charles Dickens wrote about the railroad workers in 'Another Railroad Author'; in 'Bleak House and Hard Times' he wrote about mill owners' resistance to measures to ameliorate cruel working conditions. Charles Kingsley's famous work 'The Water Babies' drew attention to the inhumane conditions of chimney sweeps, who were usually young orphan children. Many of these works actually propelled changes in law and practice. Even so, artistic responses are not unidirectional nor are they single-mindedly hurtling to change law and policy.

Guernica, arguably the most famous and effective work in response to brutal bombing of a village in Spain by the fascist forces of General Franco. Yet, in spite of its historical reference, today the painting is admired and enjoyed foremost being a work of art, which opened up new possibilities in formal elements and aesthetic experiments-Quddus Mirza, Awaaz Baldia Factory Inferno: Artists Respond (February 2013) ${ }^{1}$

After the Ali Enterprises Factory Fire, there was no notable workers' strike in Karachi, much less, across Pakistan; even workers' protests were slow to come. ${ }^{2}$ There wasn't even an overwhelming and unified response from civil society organizations but the artists seem to have responded overwhelmingly. There were three different types of artistic responses to the Ali Enterprises Factory Fire, including artists in Pakistan and abroad; over 100 works were contributed by artists, including a permanent monument at the Pakistan Institute for Labor Education and Research (PILER). ${ }^{3}$ The Vasl Artists' Association, directed by Adeela Suleman, gave out a call for submissions to which artists responded in the Multitudes. This culminated in the exhibit titled: 'Awaaz Baldia Factory Inferno: Artists Respond' [hereinafter 'Awaaz exhibit'] which was hosted at the Arts Council of Pakistan in February 2013 in Karachi. Popular singer and political worker, Jawad Ahmed wrote a song titled 'Sun lo ke hum mazdoor hain' (listen to us, the workers!) which was first

\footnotetext{
${ }^{1}$ Qudus Mirza is an art critic, artist and independent curator $<$ http://vaslart.org/quddus-mirza/ $>$; 'Awaaz: the Baldia Factory Inferno Artists Respond', February 8-15, 2013, Arts Council of Pakistan, Karachi.

2'Labour Unions to hold worldwide protests for Baldia Fire victims', 21 March 2016, https:// tribune.com.pk/story/1069544/going-global-labour-unions-to-hold-worldwide-protests-for-baldiafire-victims/.

3،Jawad Ahmed to dedicate his latest song to Baldia's victims', 23 December 2012, https://tribune. com.pk/story/483214/singer-jawad-ahmed-to-dedicate-his-latest-song-to-baldias-victims/; Jawad Ahmed, 'Sun lo ke hum mazdoor hain' (listen to us, the workers!), Love and Revolution (2013), https://www.youtube.com/watch? $\mathrm{v}=\mathrm{oDMVoCFej7E}$; 'Artists pay tribute to the Baldia fire victims', 10 February 2013, https://www.dawn.com/news/784929; ‘Awaaz: the Baldia Factory Inferno Artists Respond', 8-15 February 2013, Arts Council of Pakistan, Karachi; 'Unique memorial erected for 2012 Baldia factory fire victims', 11 September 2013, https://arynews.tv/en/uniquememorial-erected-for-2012-baldia-factory-fire-victims/; 'German artist relives Baldia factory fire', 24 November 2016, https://tribune.com.pk/story/1242427/bringing-art-life-german-artist-relivesbaldia-factory-fire/.
} 
introduced during the Awaaz Exhibit and then videographed with all the families of the victims of the fire at the first anniversary of the fire. The song not only moved everyone but also became an anthem for workers to rally around. It soon began to be sung at meetings of the Ali Enterprises Factory Fire Affectees Association (AEFA), and at other meeting or conferences organized with the aim to improve labour conditions and terms of employment. ${ }^{4}$ In 2016, the Vasl Artists' Association also hosted an artist residency centered on the Ali Enterprises Factory Fire, 2012. German artist Miro Cramer participated in the residency and produced work that was exhibited in public market places, various college campuses, such as Indus Valley School of Art and Architecture and Iqra University, across Karachi, and at the Textile Industry Museum in Augsburg, Germany. ${ }^{5}$ Since Adeela Suleman was a driving force behind the artists' response to the Ali Enterprises Factory Fire, it was important to bring this conversation to this book.

Palvasha Shahab: There were three different types of artistic responses to the Ali Enterprises Factory Fire, including artists in Pakistan and abroad; over 100 works were contributed by artists, including your permanent monument, which is now installed on the campus for Pakistan Institute for Labor Education and Research (PILER). Why do you think there was such an overwhelming response to the Ali Enterprises Factory Fire from the artists? What do you think were the motivations behind that?

Adeela Suleman: I think people's senses were numb. An event of such magnitude sometimes leads to total silence by the people who are directly affected by it. What is the role of Art in the wake of tragedy? We, as artists, ask this question all the time. It took me 3 months to respond to the catastrophe, the pain was unimaginable. What I experienced-mourning isn't an event; it's a state of mind, always there, shifting forward, staying, withdrawing, always growing, like a shadow, it follows you around. You can't let go of it but one can certainly learn to channel it.

Art also reaffirms why we must never allow something like that to happen again. When we think of art or the artists that respond to tragedy-art on terrorism like $9 / 11$, suicide bombings or art that responds to genocide, such as the millions of pieces that respond to the Holocaust-our assumption is that the art works will be sad, frightening and powerful. This is not necessarily true but they will appeal to

\footnotetext{
4'Singer Jawad Ahmed dedicates his HR Award to labourers, working people', 21 December 2016, https://dailytimes.com.pk/39296/singer-jawad-ahmed-dedicates-his-hr-award-to-labourers-work ing-people/; 'Six years after the Baldia factory fire, working conditions still not changed', 10 September 2018, https://tribune.com.pk/story/1799215/1-six-years-baldia-factory-fire-work ing-conditions-still-not-changed/; "Law, Judicial Interventions and Social Change, with a special focus on Labor Law", organized by The Rasheed Razvi Centre for Constitutional and Human Rights (RCCHR), 21st and 22nd September 2019, IBA- City Campus, Karachi, Pakistan https:// www.youtube.com/watch? $=$ LHz4t6zGs_g.

5'Artist residency in Pakistan' October-December 2016, https://www.lahorebiennale.org/artistresidency-in-pakistan/; 'German artist relives Baldia factory fire', 24 November, 2016, https:// tribune.com.pk/story/1242427/bringing-art-life-german-artist-relives-baldia-factory-fire/.
} 
pathos, reminding us of the emotional horrors, such as of the Holocaust and of people dying through suicide bombings, and reminding us of the work needed to prevent these in the future.

The Exhibition Awaaz was evidence that art can, in its distanced way, channel sorrow and even help with the healing process. More than 100 artists designers, creative organizations, individuals responded to the call for work. The Citizens Archive of Pakistan (CAP) presented a two-part exhibit that included a timeline tracing the history of major fires in the country over the past 50 years. The second part was an interactive 'moving exhibit' where the CAP team wore special T-shirts, firemen helmets and carried fire extinguishers to create awareness about fire safety. All material created for the exhibit was displayed with concise fire safety information and emergency phone numbers.

I made a film installation; Muzzumil Ruheel printed black and white faces of all the 256 victims and after numerous prints the prints started to fade, becoming invisible. It was the center piece of the exhibition, it was moving and powerful. Hassan Mustafa and Owais Ahmed Khan also made a three dimensional and a video installation in which they actually got the burnt jeans from the site of the Ali Enterprises Factory - these jeans had been lying around the building. Along with that they made a video collage of the 'breaking news' broadcasts that came on that horrific day. Manizhe Ali made a video in which she sat in front of the dressing table and applying make-up on her self and in the background one could hear the television news covering the incident, ambulance sirens; and she sat there seemingly oblivious of what is happening around her. The exhibition was very powerful and it moved everyone. People had tears in their eyes.

Sohail Zuberi a designer and photographer, made posters to mark the horrific event for next 4 years.

I made a wall monument to mark the first anniversary of the AE fire. It was initially installed at the Arts Council of Pakistan, Karachi. All the family members were invited and they all lit diyas (traditional clay oil lamps) to remember their loved ones and placed them in niches in the wall. It was quite an emotional event. I don't have words to describe it - to see so many mourning families together. Each brick had the name of a victim. Later the wall was transported to be permanently installed at the Pakistan Institute of Labour Education \& Research (PILER) campus in Karachi.

Palvasha Shahab: How did you perceive the Ali Enterprises Factory Fire? How do you think your contemporaries/fellow artists perceived it? A failure of the State? A human tragedy? A tragedy of the working class? An inevitable result of unchecked capitalism?

Adeela Suleman: I think all of the above-it was a wide-ranging state failure, an unimaginable and inconceivable human disaster, an unbearable and agonizing tragedy for the working class and the inevitable and predictable result of inhuman capitalism. That is why monuments are important-it comes from the Latin words Moneo or Monere which means 'to advise', 'to remind' or 'to warn'. And this reminder, whether it's in the form of an exhibition like the Awaaz or a permanent monument like the one I installed at Pakistan Institute for Labour Education and 
Research (PILER) campus, which I built with bricks representing the 256 victims, or any other form - it serves as a piece of advice and as a warning to the living that this could have been them and/or they have to ensure that this is not repeated again ever.

Through a simple call for works, we received overwhelming response-more than 100 art works, performances, video works were exhibited. Jawad Ahmed's song 'Sun Lo Kay Hum Mazdoor Hain' (Listen to us, the workers!) was performed at the Ali Enterprises Factory site and then the video was played at the first anniversary against the backdrop of the wall monument I made. It brought tears to the eyes of not just the victims' families but everyone who was present there.

Contemporary artists are the inheritors of a modernist tradition of dealing passionately with calamity. If you observe art history you will find that art and tragedy often walk hand-in-hand. There is a long-standing tradition involving artists who decided to capture the tragedies of their time. Artists ranging from Goya to Picasso expressed their outrage over specific tragic events upon canvas-the connection between art and tragedy goes further back and becomes more recent than that. From Homer's tales of Troy to Picasso's 'Guernica' from Tchaikovksy's symphony 'Pathétique' to Bill T. Jones's choreographed dance performance 'Still/Here' for an adaptation of Shakespearean drama to Maya Lin's Vietnam Memorial, artists have always combated grave tragedy with intense beauty. Romantic Spanish painter Francisco Goya traveled from Madrid to Saragossa in 1808 to witness the awful consequences of the French siege. The result was his unequaled suite of etchings, 'The Disasters of War' in which we see three nude men strung up on a dead tree. Goya also painted the second most famous outcry against the consequences of merciless war, the 13-foot-wide 'The Third of May, 1808' which depicts, in slashing brushstrokes and dramatic color, the massacre of defenseless civilians by a ruthless military. The words of the British poet Wilfred Owen, written at the front in the First World War, are almost mandatory: "All a poet can do today is warn. That is why the true poets must be truthful." But even that hard-won wisdom may not be enough for an artist trying with all his heart to create a work profound enough to do justice to the horrors the world witnesses.

Palvasha Shahab: It appears that you are deeply embedded in Karachi, and in the city's art milieu; you have produced art here for a long time. What do you think was the significance of your work about the Ali Enterprises Factory Fire? Was this a passing moment in the city's artistic milieu or is the consciousness changing? Are artists in Karachi becoming more engaged with the city? Are they finding new ways to connect with the world? Why do you think this fire was significant to artists from outside Pakistan?

Adeela Suleman: I believe nothing provokes the artistic sensibility like grief. One can even say it's a selfish act because we see someone else's pain and make a visual out of it. But that is the only language we speak, a way to retain our sanity, that is the only way we can respond to such an event, that is the only way we can show the others that we have not forgotten them.

Karachi is a mad city_-jarring experiences all around. It's difficult for artists to ignore the atrocities that the city is functioning with. Having been a teacher for 
almost two decades, I can't remember a single year where my students are not directly responding to this city. It's overwhelming; its impossible not to respond to it.

Like historians, artists visually document the events in their time. They try to narrate their experiences by evoking and generating feelings in the viewers.

Palvasha Shahab: What is the relationship between art and politics, in your opinion? What do you think are the implications of and possibilities of political art? Artists and writers such as Upton Sinclair, Charles Dickens, Lewis Hine have contributed significantly to labor movements, and to other movements for liberation or social justice. In producing works of art in response to tragedies and ruptures like the Ali Enterprises Factory Fire, how do you place yourself and your work within these debates?

Adeela Suleman: Dada poet Hugo Ball says, "For us, art is not an end in itself ... but it is an opportunity for the true perception and criticism of the times we live in."

In a country like Pakistan I have personally recently discovered the true immensity of art's power. The visual or image created by artists can jolt the entire establishment, tug at the heartstrings of society, it can stir opinion, and even have global impact.

Art is political - all art forms are political-there is no doubt in that. Art complicates our understandings and insights of the world. It alters the discursive frames within which the political is negotiated. Art is also political because it reinterprets what previously was seen and known so that alternative understandings may emerge. These reinterpretations help reveal existing power relations within society, and reexamine what was previously known and what was deemed worthy of analysis in the first place in the context of what was not seen previously and (therefore?) was not known. It also brings to light what should be seen or known. I think this is perhaps exemplified by my work titled: 'The Killing Fields of Karachi', which was installed in the courtyard of the Frere Hall, adjacent to a huge public garden in Karachi. Frere hall was constructed, in 1865, during the British era as a Town Halland to me, it is noteworthy feature on Karachi's landscape, a reminder of the British Raj and its unchecked power in the Indian Sub-Continent. The installation had 444 pillars shaped like graves - each standing adjacent to the building becoming part of the surrounding landscape. It represented 444 victims of extra-judicial killings and fake police encounters by a police officer named Rao Anwar, who was covertly known to be a gun for hire. To me he is a symbol of terror and the immense power of capitalism and the deep state. Rao Anwar became wellknown after his encounter of Naqeebullah Mehsud, a young Pashtun man, whose death fueled the Pashtun Tahafuz Movement (a movement against systemic discrimination against and demonization of people of the Pashtun ethnicity in Pakistan). The 'Killing Fields of Karachi' interpreted and visually represented Rao Anwar's reality and brought it to the public. Those 444 pillars juxtaposed with the mightly colonial building and the charming public garden scared the establishment, the powers that be, to the extent that the work was shut down within the first $2 \mathrm{~h}$ of its unveiling at the Karachi Biennale 2019 (which was a 2-week long event). The work captured the pain, sorrow and loss. The work also depicted the powerlessness and impuissance of the victims and their families. 
I think art is a more effective means of communicating the experience of pain than words ever could be. A painful experience goes beyond the actual occurrence of physical pain and it surrounds the entirety of one's life. The best of the art comes out of pain, in one form or another. Pain is universal; this is perhaps a major reason why art can break down barriers and brings people together.

Many artists use their visual language to highlight the grave injustices in their societies. For example, the work of Ai Wei Wei titled: 'Sunflower Seeds' consists of 100 million ceramic husks created to resemble in size, color and shape their counterparts from nature. The husks were produced for Wei Wei by 1600 artisans who suffered mass unemployment, in Jingdezhen, China, a town where imperial porcelain has been made for over a 1000 years. Francisco de Goya's masterpiece, 'The Third of May 1808', depicts a long trail of Spanish rebels lining up to be executed by French troops. The viewer's eye is immediately drawn to the rebel figure wearing white, his arms raised, he has a harrowed expression as he faces the French soldiers readying to gun him down. Works of art allow us to forge deeper emotional bonds with the people who actually lived in different times and places, as well as in our own times. These works of art serve as windows to the soul of their times.

Art also forces us to remember. To produce his work, Gerhard Richter looked at the photographs of Andreas Baader, Jan-Carl Raspe, and Gudrun Ensslin from newspaper and their police photographs their television images. Andreas Baader, Jan-Carl Raspe, and Gudrun Ensslin were found dead in their cells in a Stuttgart prison on October 18, 1977. The three were members of the Red Army Faction, a coalition of young political radicals jointly led by Baader and Ulrike Meinhof (who had hung herself in police custody earlier). Having turned to violence in the late 1960s, the Baader-Meinhof group had become Germany's most feared radicals. Although the prisoners' deaths were pronounced suicides, the authorities were suspected of murder. Gerhard Richter's slurred and murky motifs derived from newspapers and police photographs or television images. Shades of gray dominate the work; the absence of color conveys the way these secondhand images from the mass media sublimate their own emotional content. The visual that Richter created made his work the most challenging work of his career, according to him. The almost cinematic repetition gives an impression, as if in slow motion, of the tragedy's inexorable unfolding. Produced during a prosperous, politically conservative era, 11 years after the actual events-the work insisted that this painful and controversial subject be remembered.

Many of us are blind to the realities of loss and mourning until we're confronted with them: a devastating news headline, a live broadcast of war images, a lifeless animal on the side of the road, or the life-altering loss of a loved one. Great art speaks not just to the pain experienced, but also looks toward the day where we are able to move forward or are able to or learn to live with the pain. As Henri Frédéric Amiel, Swiss moral philosopher, poet and critic said, "you desire to know the art of living, my friend? It is contained in one phrase: make use of suffering". 
Palvasha Shahab was the joint executive director of the Rasheed Razvi Centre for Constitutional and Human Rights, and the Legal Aid Foundation for Victims of Rape and Sexual Assault through September 2020. She now works a consultant for RCCHR, LAFRSA, the Legal Aid Society and the Pakistan Institute for Labour Education and Research. She is on the Law Committee of the Sindh Commission of the Status on Women and advises on upcoming legislation. She is also an advisor to a transnational collaborative project on oral histories and social interventions titled "Karachi Beach Radio." She also teaches undergraduate courses on peace movements and international human rights law at SZABIST, Karachi. Shahab further curates and moderates important public discussions on national platforms such as the Adab Fest and The Second Floor. She holds a Master of Laws from Columbia Law School, New York, US, where she was also a Human Rights Fellow at the Human Rights Institute in 2017-2018.

Open Access This chapter is licensed under the terms of the Creative Commons Attribution 4.0 International License (http://creativecommons.org/licenses/by/4.0/), which permits use, sharing, adaptation, distribution and reproduction in any medium or format, as long as you give appropriate credit to the original author(s) and the source, provide a link to the Creative Commons license and indicate if changes were made.

The images or other third party material in this chapter are included in the chapter's Creative Commons license, unless indicated otherwise in a credit line to the material. If material is not included in the chapter's Creative Commons license and your intended use is not permitted by statutory regulation or exceeds the permitted use, you will need to obtain permission directly from the copyright holder.

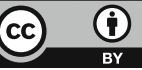

